\title{
Makna Teks Ujaran Kebencian Pada Media Sosial
}

\author{
Dita Kusumasari dan S. Arifianto \\ Puslitbang Aptika dan IKP, Kementerian Komunikasi dan Informatika \\ Jalan Medan Merdeka Barat No. 9, Jakarta Pusat, 10110 \\ dita.kusumasari@gmail.com, arief2008@gmail.com
}

Masuk tanggal : 16-05-2019, revisi tanggal : 29-07-2019, diterima untuk diterbitkan tanggal : 25-08-2019

\begin{abstract}
Public sphere in social media, which should be used for information exchange, science, also democratic and independent values, currently are partially replaced by certain political economic matters. The public sphere has shifted into media of spreading hate speech. For that reason, this study aims to explain the meaning of the use of public sphere for presence of hate speech texts which are constructed to attack others with differing ideological and political views; also describes factors that affect the use of hate speech. This study applies phenomenological approach to the text of speech hate on social media and its critical impact in Indonesia. Data collection is done through observation, comparison theory, and literature studies. By referring the concept of Habermas (1989) related public sphere, supported by expert statements and qualitative data; conclusions of this article show that public sphere in social media is no longer functioning as a communication media, where thought and knowledge are exchanged for values in a dialogical, independent and democratic way. Its existence has partially replaced by capitalist economic forces and pragmatic politics in order to achieve certain goals instantly, at the expense of its values and social cultural ethics.
\end{abstract}

Keywords: hate speech, political economic value, public sphere, social media

\begin{abstract}
Abstrak
Ruang publik pada media sosial, yang seharusnya berfungsi sebagai tempat pertukaran gagasan dan ilmu pengetahuan dengan nilai-nilai secara demokratis dan independen, sebagian kini telah tergantikan oleh kekuatan ekonomi politik tertentu. Fungsi ruang publik tersebut kini telah bergeser sebagai arena penyebaran teks ujaran kebencian, yang menyebabkan audiens mengalami kesulitan dalam membedakan informasi yang akurat dengan teks yang berupa berita palsu, termasuk ujaran kebencian. Oleh karena itu, studi ini bertujuan untuk menganalisis makna teks ujaran kebencian yang beredar melalui saluran media sosial. Artikel ini menjabarkan penggunaan ruang publik atas hadirnya teks ujaran kebencian yang dikonstruksi untuk menyerang pihak lain dengan pandangan ideologi dan politik yang berbeda; serta menjelaskan faktor yang berpengaruh terhadap penggunaan teks ujaran kebencian. Penelitian ini menerapkan pendekatan fenomenologi terhadap teks ujaran kebencian pada media sosial dan dampak kritisnya di Indonesia. Pengumpulan data dilakukan melalui observasi, perbandingan teori, dan studi literatur. Dengan penjabaran yang mengacu pada konsep Habermas (1989) tentang ruang publik, didukung data kualitatif dan argumen lainnya, simpulan dalam artikel ini menunjukkan bahwa ruang publik pada media sosial bukan lagi hanya berfungsi sebagai arena berkomunikasi, tempat pemikiran dan pengetahuan dipertukarkan nilai nilai secara dialogis, independen dan demokratis. Keberadaannya sebagian telah tergeser oleh
\end{abstract}


kekuatan ekonomi kapitalis dan politik pragmatis untuk mencapai tujuan tertentu yang bersifat instan, dengan mengorbankan nilai dan estetika sosial budayanya.

Kata Kunci: media sosial, nilai ekonomi politik, ruang publik, ujaran kebencian

\section{Pendahuluan}

Media sosial sebagai ruang publik berperan sebagai media untuk berdiskusi, bertukar pikiran, serta berkomunikasi secara bebas dan demokratis. Saat ini peran tersebut mulai terganggu dengan adanya intervensi kekuatan ekonomi politik oleh kelompok tertentu, sehingga netralitas masyarakat dalam bermedia terusik. Media sosial yang selayaknya berguna untuk membangun kebebasan berpendapat dan solidaritas demokrasi, justru digunakan sebagai alat penyebaran teks ujaran kebencian untuk menggiring opini publik, bahkan menyerang 'lawan' yang memiliki perbedaan pandangan dan ideologi. Persebaran teks ujaran kebencian tersebut dilakukan bukan sekedar oleh unsur ketidaksengajaan, bersifat iseng, atau hiburan semata, tetapi dapat diasumsikan memiliki agenda setting tertentu.

Teks ujaran kebencian pada media sosial telah bermetamorfosis menjadi bagian dari sebuah panggung ekonomi politik yang dengan sengaja dirancang oleh pihak tertentu untuk mendapatkan keuntungan dibalik wacana dan produksinya. Selain meresahkan masyarakat pengguna informasi, saat ini teks ujaran kebencian di media sosial juga telah menjadi ancaman bagi demokrasi kebebasan pers, sebagai ruang publik di Indonesia. Pada konteks ini, selain mengalami kesulitan dalam menentukan teks informasi mana yang bersifat akurat dan teks informasi mana yang merupakan berita palsu/hoax, masyarakat juga menemui kesulitan dalam membedakan antara teks informasi yang bersifat kritik di ruang publik, dengan teks ujaran kebencian. Akibatnya masyarakat pengguna ruang publik di media sosial kerap mempercayai informasi yang mengandung teks ujaran kebencian tersebut dengan mengunggah ulang dan meneruskan pesan tersebut melalui media sosial terkait, sehingga berimplikasi pada penyebaran teks ujaran kebencian dengan cepat dan menjangkau audiens yang luas.

Jenkins, Ford \& Green (2009) melihat bahwa perkembangan teknologi informasi komunikasi digital telah melipatgandakan percepatan pesan media, yang memunculkan praktik dan nilai-nilai dalam berbagi konten di media digital. Media sosial (seperti Facebook, YouTube, Twiter, Path, Instagram) merupakan salah satu platform media digital yang berperan sebagai ruang publik, dimana praktek budaya demokrasi masyarakat dalam bertukar gagasan dan pendapat terjadi. Melalui penggunaan media sosial yang bersifat spreadability ini, secara teknis memberikan peluang bagi penggunaya untuk berbagi ragam konten secara independen.

Media sosial diasumsikan dapat mendorong keterlibatan penggunanya untuk mensirkulasikan pesan komunikasi secara online, meski informasi yang dikonsumsi belum tentu jelas kebenarannya. Masyarakat modern, khususnya generasi milenial memiliki akses luas dalam menyebarkan informasi karena dukungan perangkat TIK berbasis internet yang memadai, sehingga 
memungkinkan seseorang untuk menjadi produsen sekaligus konsumen terhadap konten informasi (Vainikka \& Herkman, 2013). Hal ini menjadikan tantangan yang dihadapi oleh pemangku kebijakan menjadi semakin kompleks.

Para prosumer diibaratkan sebagai wartawan independen, di mana mereka dapat mengkonsumsi, mereproduksi, dan mendistribusikan ragam konten informasi termasuk ujaran kebencian, baik secara individu, maupun kelompok. Pada media sosial, ujaran kebencian dirujuk dalam bentuk ekspresi (tulisan, ucapan, pidato, orasi), yang bersifat persuasif untuk menghasut anggota, kelompok, organisasi, atau kalangan tertentu, dengan membuat akun anonim untuk menyembunyikan identitasnya. Mulai dari Pilpres 2014, Pilgub DKI Jakarta 2017, Pilpres 2019, hingga saat ini, postingan teks ujaran kebencian di media sosial masih menjadi isu yang fenomenal. Pada Maret 2018, pencemaran nama baik di media sosial kembali diperbincangkan. Arseto Suryoadji resmi menjadi tersangka dalam kasus ujaran kebencian terkait unggahan video ke Facebook dan Instagram, yang menyebut pendukung Joko Widodo menjual undangan pernikahan putri Jokowi dengan harga Rp 25 juta. Dalam video viral tersebut, Arseto juga menyebut Jokowi dan para pendukungnya sebagai koruptor.

Jika merujuk pada konteks ini kebebasan berekspresi dalam media sosial seakan lepas kendali. Padahal kebebasan individu dalam bermedia juga dibatasi kebebasan yang sama oleh orang lain. Maka kepatuhan terhadap etika profesi dan nilai moralitas dalam bermedia menjadi sangat substansif. Teks ujaran kebencian yang beredar di berbagai media sosial antara lain mengandung, penghinaan, pencemaran nama baik, penistaan, perbuatan tidak menyenangkan, provokasi, dan upaya menghasut. Sedangkan aspek yang diangkat meliputi permasalahan suku, agama/kepercayaan, ras, golongan, warna kulit, etnis, gender, hingga kaum difabel. Ketika media sosial, dianggap sebagai ruang publik yang demokratis, gesekan konten media yang terjadi merupakan fenomena yang wajar. Hal ini disebabkan keragaman sudut pandang dalam melihat persoalan sosial dan budaya diruang publik. Konsep ruang publik sebagai tempat berdialog, berkomunikasi, dan negosiasi di media sosial dapat digunakan untuk menjelaskan penyebaran teks ujaran kebencian.

Public sphere can be described as a domain of our social life in which such a thing as public opinion can be formed. Access to the public sphere is open in principle to all citizens. A portion of the public sphere is constituted in every conversation in which private persons come together to form a public. They are then acting neither as business or professional people conducting their private affairs, nor as legal associates subject to the legal regulations of state deal with matters of general interest without being subject to coercion; thus with the guarantee that they may assemble and unite freely; and express and publicize their opinions freely (Habermas, 1989 dalam Alan McKee, 2005).

Konsep Habermas ini mengutamakan dialogical conception dengan asumsi individu-individu datang bersama ke lokasi yang sama, dan terjadinya dialog dalam percakapan face to face (dalam Oliver Boyd-Bareet, 1995). Konsep ruang publik tersebut dianalogikan dalam penggunaan media sosial sebagai arena komunikasi dialogis bagi semua orang secara bebas dan demokratis. Bahkan 
potensi kebebasan ruang publik tersebut dapat digunakan sebagai arena edukasi negosiasi ekonomi politik secara demokratis oleh para penggunanya (Sibert, 1973). Kondisi tersebut hanya dapat terjadi jika diantara penggunanya memenuhi etika bermedia yang demokratis dan egaliter. Penyebar teks ujaran kebencian dalam konteks bermedia tentu bukan suatu gerakan yang muncul dengan sendirinya, melainkan memiliki akar permasalahan dan tendensi yang menjadi pendorong, juga arah sasaran penyebarannya.

Jika ditelusuri hampir semua konflik yang muncul di media sosial selalu dipicu oleh teks ujaran kebencian dari individu/kelompok tertentu yang berseberangan pandangan dengan kelompok lain, karena perbedaan ideologi, politik, dan kepentingan lain. Sementara menurut Surat Edaran Mabes Polri No:SE/6/X/2015, tanggal 8 Oktober 2015, ujaran kebencian di definisikan sebagai "tindak pidana yang berbentuk, penghinaan, pencemaran nama baik, penistaan, perbuatan yang tidak menyenangkan, memprovokasi, menghasut, penyebaran berita bohong, dimana semua tindakan di atas memiliki tujuan atau bisa berdampak pada tindak diskriminasi, kekerasan, penghilangan nyawa, dan atau konflik sosial". Definisi ujaran kebencian dalam Surat Edaran ini setidaknya dapat digunakan untuk mengidentifikasi indikator teks ujaran kebencian di berbagai media, termasuk media sosial.

Berdasarkan pemaparan terkait fenomena penyebaran hate speech pada media sosial yang telah berlangsung selama beberapa tahun tersebut, akan menjadi menarik untuk diamati dan dianalisis makna serta dampaknya pada masyarakat melalui konsep dan teori komunikasi.

\section{Metode Penelitian}

Metodologi penelitian dirancang untuk mengumpulkan informasi yang akurat dari parameter yang diamati. Penelitian ini merupakan studi fenomenologi terhadap teks ujaran kebencian pada media sosial dan dampak kritisnya di Indonesia. Pendekatan fenomenologi merupakan bentuk penelitian kualitatif yang dimulai dengan memperhatikan dan menelaah fokus fenomena yang akan diteliti, dengan memperimbangkan berbagai aspek subjektif dari perilaku objek (Johnson \& Onwuegbuzie, 2004). Selanjutnya, peneliti melakukan penggalian data berupa pemaknaan objek terhadap fenomena terkait.

Pengumpulan data dilakukan melalui observasi, perbandingan teori, dan studi literatur. Data sekunder diperoleh melalui berbagai sumber, antara lain Kitab Undang-Undang Hukum Pidana (KUHP), Undang Undang no.11/2008 tentang Informasi dan Transaksi Elektronik, serta Undang Undang no.40/2008 tentang Penghapusan Diskriminasi Ras dan Etnis. Proses triangulasi dilakukan sepanjang proses pengumpulan dan analisis data dukung untuk mendapatkan temuan yang objektif.

Analisis yang dilakukan masih terbatas pada pemaknaan dalam relasi penggunaan ruang publik dengan konsep teks ujaran kebencian, serta faktor yang berpengaruh terhadap berkembangnya ujaran kebencian di media sosial. Konklusi pada akhir artikel berupa identifikasi dampak dan saran terkait pencegahan 
persebaran teks ujaran kebencian di ruang publik media sosial yang dianggap meresahkan masyarakat.

\section{Hasil Penemuan dan Diskusi}

Artikel ini mencakup dua fokus diskusi. Pertama, menjelaskan dan mengekplorasi pemaknaan teks ujaran kebencian pada media sosial yang digunakan oleh pihak-pihak tertentu untuk menyerang individu/ kelompok/ pihak lain yang berbeda dalam ideologi, afiliasi politik dan tujuan. Kedua menganalisis faktor-faktor yang berpengaruh terhadap penggunaan teks ujaran kebencian di media sosial. Dengan demikian, artikel ini belum melakukan pembahasan terkait indikator sebagaimana yang didefinisikan dalam SE/6/X/2015 tanggal 8 Oktober, 2015.

Selama ini dipahami banyak pihak, bahwa setiap isu fenomenal yang menjadi viral di media sosial, terdapat pihak-pihak tertentu yang diuntungkan dan dirugikan, tergantung dari sudut pandang masing-masing. Idealnya semua media didudukkan sebagai sebuah institusi independen dan demokratis, dimana setiap kinerja operasionalnya selalu mengutamakan azas keseimbangan, praduga tidak bersalah, serta kebebasan berekpresi. Artinya kebebasan media bukan berarti absolut, tetapi tetap berpijak pada kebebasan yang bertanggung jawab sesuai kode etiknya.

Media mainstream telah memiliki kode etik jurnalisme/penyiaran, yang digunakan sebagai mekanisme kontrol terhadap kinerja para jurnalisnya. Sementara media sosial tidak dapat diperlakukan sama. Penyelenggara platform media sosial umumnya tidak berdomisili di Indonesia. Implikasinya ketika terjadi pelanggaran penggunaan ruang publik seperti kasus "teks ujaran kebencian" yang bertautan dengan individu/kelompok/organisasi di Indonesia, akan menjadi sulit ditangani secara hukum. Idealnya jika tindakan pelanggaran hukum dilakukan di wilayah Indonesia, mereka yang melakukan wanprestasi, termasuk tindakan penyebar teks ujaran kebencian dapat dijerat dengan pasal dan ayat dalam perangkat hukum yang berlaku di Indonesia sebagai berikut ini:

1. Barangsiapa di muka umum menyatakan perasaan permusuhan, kebencian atau penghinaan terhadap suatu atau beberapa golongan rakyat Indonesia, diancam dengan pidana penjara paling lama empat tahun atau pidana denda paling banyak empat ribu lima ratus rupiah - KUHP, Pasal 156

2. 1). Barangsiapa menyiarkan, mempertunjukan atau menempelkan tulisan atau lukisan di muka umum, yang isinya mengandung pernyataan perasaan permusuhan, kebencian atau penghinaan di antara atau terhadap golongangolongan rakyat Indonesia, dengan maksud supaya isinya diketahui oleh umum, diancam dengan pidana penjara paling lama dua tahun enam bulan atau pidana denda paling banyak empat ribu lima ratus rupiah.

2). Jika yang bersalah melakukan kejahatan tersebut pada waktu menjalankan pencariannya dan pada saat itu belum lewat lima tahun sejak pemidanaannya menjadi tetap karena kejahatan semacam itu juga, yang bersangkutan dapat dilarang menjalankan pencarian tersebut - KUHP, Pasal 157 Ayat (1) dan (2) 
3. 1). Barangsiapa sengaja menyerang kehormatan atau nama baik seseorang dengan menuduhkan sesuatu hal, yang maksudnya terang supaya hal itu diketahui umum, diancam karena pencemaran dengan pidana penjara paling lama Sembilan bulan atau pidana denda paling banyak empat ribu lima ratus rupiah.

2). Jika hal itu dilakukan dengan tulisan atau gambaran yang disiarkan, dipertunjukan atau ditempel di muka umum, maka diancam karena pencemaran tertulis dengan pidana penjara paling lama satu tahun empat bulan atau pidana denda paling banyak empat ribu lima ratus rupiah.

3). Tidak merupakan pencemaran atau pencemaran tertulis, jika perbuatan jelas dilakukan demi kepentingan umum atau karena terpaksa untuk membela diri - KUHP, Pasal 310 Ayat (1), (2), dan (3)

4. Jika yang melakukan kejahatan pencemaran atau pencemaran tertulis dibolehkan untuk membuktikan apa yang dituduhkan itu benar, tidak membuktikannya dan tuduhan dilakukan bertentangan dengan apa yang diketahui, maka dia diancam melakukan fitnah dengan pidana penjara paling lama empat tahun - KUHP, Pasal 311 Ayat (1)

5. 1). Setiap Orang dengan sengaja dan tanpa hak menyebarkan berita bohong dan menyesatkan yang mengakibatkan kerugian konsumen dalam Transaksi Elektronik.

2). Setiap Orang dengan sengaja dan tanpa hak menyebarkan informasi yang ditujukan untuk menim -bulkan rasa kebencian atau permusuhan individu dan/atau kelompok masyarakat tertentu berdasarkan atas suku, agama, ras dan antar golongan (SARA) - UU No.11 Tahun 2008 tentang ITE, Pasal 28

6. Setiap Orang yang memenuhi unsur sebagai -mana dimaksud dalam Pasal 28 ayat (1) atau ayat (2) dipidana dengan pidana penjara paling lama 6 (enam) tahun dan/atau denda paling banyak Rp 1.000.000.000,00 (satu miliar rupiah) - UU No.11 Tahun 2008 tentang ITE, Pasal 45

7. Pasal 16: Setiap Orang yang dengan sengaja menunjukkan kebencian atau rasa benci kepada orang lain berdasarkan diskriminasi ras dan etnis sebagaimana dimaksud dalam Pasal 4 huruf b angka 1, angka 2, atau angka 3 , dipidana dengan pidana penjara paling lama 5 (lima) tahun dan/atau denda paling banyak Rp.500.000.000,00 (lima ratus juta rupiah) UU No.40 Tahun 2008 tentang Penghapusan Diskriminasi Ras dan Etis

Berdasarkan pendapat para ahli hukum, pasal-pasal dalam perangkat hukum yang telah dipersiapkan pada Undang Undang tersebut masih belum mampu meredam penyebaran teks ujaran kebencian (hate speech) di ruang publik media sosial secara optimal, kecuali UU No. 11/2008/ tentang ITE. Saat ini teks ujaran kebencian justru berkembang semakin masif, dan digunakan oleh kelompok tertentu untuk menyerang individu/ kelompok/ pihak lain yang berseberangan ideologi, dan afiliasi politiknya di ruang publik media sosial (Chazawi, 2011). 
Intensitas penggunaan teks ujaran kebencian ini pada kisaran tahun 20182019 diasumsikan akan mengalami kenaikan yang signifikan, terkait adanya kegiatan politik berskala Nasional yakni, Pilkada serentak (2018) dan Pemilu sekaligus Pilpres pada tahun 2019. Ketiga even politik ini menjadi perhatian banyak pihak, termasuk mereka yang berperan sebagai penebar ujaran kebencian di ruang publik media sosial. Media sosial menjadi pilihan mereka bukan hanya karena kebebasannya, tetapi juga kemudahan bagi penggunaannya, termasuk produksi dan reproduksi konten dalam bentuk postingan media sosial melalui akun palsu/anonim. Pemalsuan identitas ini telah menjadi tren bagi penebar ujaran kebencian di ruang publik media sosial saat ini, baik secara formal maupun non formal. Fenomena bermedia di era teknologi informasi global ini telah mengalami pergeseran budaya baru dalam bermedia, dan keberadaannya mampu menggeser nilai-nilai etika dan makna setiap konten yang terkandung didalamnya. Bisa jadi makna teks keluar dari konteksnya, sehingga menimbulkan permasalahan sosial, budaya, ekonomi dan politik di masyarakat.

\section{Makna Teks Ujaran Kebencian}

Tindakan seseorang dalam melakukan posting berbau teks ujaran kebencian (hate speech) pada media sosial bukan tanpa makna. Keberadaan teks ujaran kebencian itu sendiri tergantung pada jenis kalimat, tujuan dan konteksnya. Berbagai kajian teks ujaran kebencian pada media sosial lebih dominan dimaknai sebagai upaya menyerang pihak lawan, ketika terjadi perbedaan ideologi, pandangan politik, ekonomi, dan kesenjangan sosial budaya pada komunitas masyarakat tertentu.

Pelaku penyebar teks ujaran kebencian dalam bentuk postingan media sosial dapat bekerja berdasarkan kepentingan individu maupun kelompok/ organisasinya. Hal ini disebabkan oleh: (1) sentimen ideologi dan pandangan politik diantara pihak yang berkompetisi, serta (2) kesenjangan ekonomi politik diantara individu/kelompok yang tertindas oleh kekuatan/pihak lain yang lebih dominan. Keduanya dapat dipicu oleh aspek ketersinggungan, dari sebuah entitas yang dirugikan dalam kompetensi ekonomi politik dan ideologi di komunitas masyarakat tertentu. Dalam kasus yang melibatkan Basuki Tjahaya Purnama (BTP) atau Ahok, pada Pilgub DKI Jakarta 2017 misalnya. BTP yang merupakan kelompok minoritas menjadi objek sasaran teks ujaran kebencian dari kelompok tertentu atas dasar isu SARA. Dalam contoh kasus tersebut dapat dilihat bahwa terjadi judgment dari suatu kelompok terhadap kelompok lain yang berbeda pandangan, melalui pemberitaan negatif pada media mainstream dan postingan pada media sosial yang dipermanenkan.

Implikasi ketika teks ujaran kebencian dipermanenkan kemudian dimaknai sebagai pembentukan kohesi sosial di masyarakat, akan menghasilkan labeling tertentu untuk mempertajam konformitas. Semakin besar tingkat konformitas dalam mengekspos ujaran kebencian, semakin besar pula potensi suatu pihak dalam menjatuhkan lawannya. Misi dari pembuat teks ujaran kebencian adalah penyampaian pesan (bersifat negatif dan provokatif) kepada pihak lawan. Motifnya dapat berupa balas dendam terhadap objek tertentu yang dianggap sebagai lawan. Kembali dalam kasus Pilgub DKI Jakarta, 2017, teks ujaran 
kebencian di ruang publik media sosial dikonstruksi bermotif defensif, dengan mengangkat isu terkait kekhawatiran terhadap kondisi DKI Jakarta yang dikuasai secara ekonomi oleh kelompok non-pribumi (kasus reklamasi Teluk Jakarta, 2017). Konten tersebut telah digunakan kubu lawan untuk menyerang kubu BTP. Kasus serupa juga pernah terjadi pada era reformasi di tahun 1998, yakni penyerangan dan penjarahan terhadap aset bisnis etnis Tionghoa di beberapa kota besar di Pulau Jawa. Kedua contoh kasus tersebut meneguhkan asumsi dan pembahasan makna dan motivasi penggunaan ujaran kebencian di ruang publik media massa dan media sosial di atas.

Studi McDevit et. all. (2002), mengindikasikan adanya motivasi lain dari pembuat teks ujaran kebencian. Dimana indikator terkait "perasaan senang atau sensasi" merupakan sesuatu yang dikejar oleh 66\% aktor pelaku yang diteliti. Dalam penelitian tersebut, aktor-aktor pelaku yang dominan dalam "mengejar kesenangan" ini bukanlah orang-orang pada level prasangka tinggi, melainkan mereka yang berada di level prasangka rendah atau sedang, sehingga orangorang ini bukan termotivasi oleh rasa benci atau dendam. Mayoritas dari mereka hanya sekedar mengikuti tren atau tidak suka sesaat terhadap objek ujaran kebencian pada suatu event atau peristiwa yang sedang berlangsung (https://tirto.id/12/10/17).

Dari kajian ini ditemukan bahwa hampir semua aturan yang ada tidak membatasi setiap ungkapan kata yang keluar dari ujaran kebencian. Artinya variabel yang digunakan untuk mengatagorikan teks ujaran kebencian (hate speech) masih bisa diperdebatkan. Konklusi kajian tersebut menggambarkan bahwa teks ujaran kebencian tidak semuanya bertendensikan perasaan dendam/benci yang diciptakan oleh individu/ kelompok/organisasi tertentu, tetapi juga banyak dipengaruhi oleh "rasa ketidaksukaan sesaat" dari individu terhadap objek tertentu, sehingga berujung pada penulisan dan penyebaran teks ujaran kebencian di berbagai media yang berdampak luas di masyarakat, termasuk media sosial.

\section{Dampak Teks Ujaran Kebencian}

Beragam pemaknaan dan penafsiran teks ujaran kebencian pada media sosial dapat menimbulkan kesulitan dalam penanganannya jika terjadi pelanggaran etika. Logika ini memberikan pandangan bahwa pendefinisian teks ujaran kebencian haruslah tepat dan sesuai konteks. Apakah ujaran kebencian tersebut berdasarkan fakta/realitas, ataukah hanya berbentuk opini publik tanpa dukungan data dan fakta yang tervalidasi eksistensinya.

Sebagai teks media, konten apapun idealnya harus terjaga, serta dapat diminimalisasi dampaknya di masyarakat. Contoh kasus teks ujaran kebencian yang berdampak luas salah satunya ketika suku Madura dan Dayak berkonflik di kota Sampit Kalimantan Barat (Januari 1999). Konflik tersebut muncul hanya karena terprovokasi oleh teks berbunyi "sape" (lembu) pada media lokal yang diucapkan oleh salah satu tokoh suku tertentu kepada suku lainnya. Teks pada media lokal tersebut ditafsirkan sebagai umpatan ujaran kebencian oleh suku lain di wilayah tersebut yang telah menyulut konflik horizontal kedua suku yang mengakibatkan banyak korban. 
Kasus lain yang terjadi yaitu pembakaran masjid di Kabupaten Tolikara Papua (Juli 2017), yang juga terprovokasi oleh teks ujaran kebencian berbau SARA di media sosial. Sama halnya pada bentrok supporter Persija Jakarta dan Persib Bandung akibat isu ujaran kebencian yang diposting pendukung Persija Jakarta di media sosial (22 Mei 2017). Postingan hoax berupa ujaran kebencian tersebut memicu aksi bentrok yang berujung pada penyerangan terhadap aparat keamanan. Merujuk dari beberapa contoh kasus yang telah dikemukakan, secara kualitatif dapat dimaknai bahwa alih alih mengkonstruksikan wahana kritik di ruang publik seperti media sosial untuk memberikan pandangan positif terhadap pihak yang berbeda aliran, pihak-pihak tertentu baik disengaja maupun tidak, cenderung menggunakan teks ujaran kebencian sebagai amunisi untuk menyerang kelemahan pihak lawannya.

\section{Faktor Pengaruh}

Teks ujaran kebencian yang diposting di ruang publik media sosial mempunyai tujuan tertentu yang lebih mendasar. Tujuan itu bisa bertendensi ekonomi, politik, atau keduanya yang paling menguntungkan aktor pemesannya. Teks ujaran kebencian sebagian besar bukan produk individu, tetapi telah diorganisir menjadi industri capital bisnis. Dimana aktornya bisa menikmati manfaat ganda, baik secara ekonomi, politik atau keduanya tergantung dari konteksnya. Model bisnis ini tidak mungkin dilegalkan, dan mereka lebih memilih bermain dibawah tangan. Kasus Saracen (2017) yang terungkap saat ini mengindikasikan makna kombinasi antara kepentingan ekonomi dan politik sesuai dengan pesanan aktor utamanya. Berikut skema ilustrasi struktur bisnis proses produk hoax teks ujaran kebencian yang sering diviralkan melalui berbagai platform di media sosial.

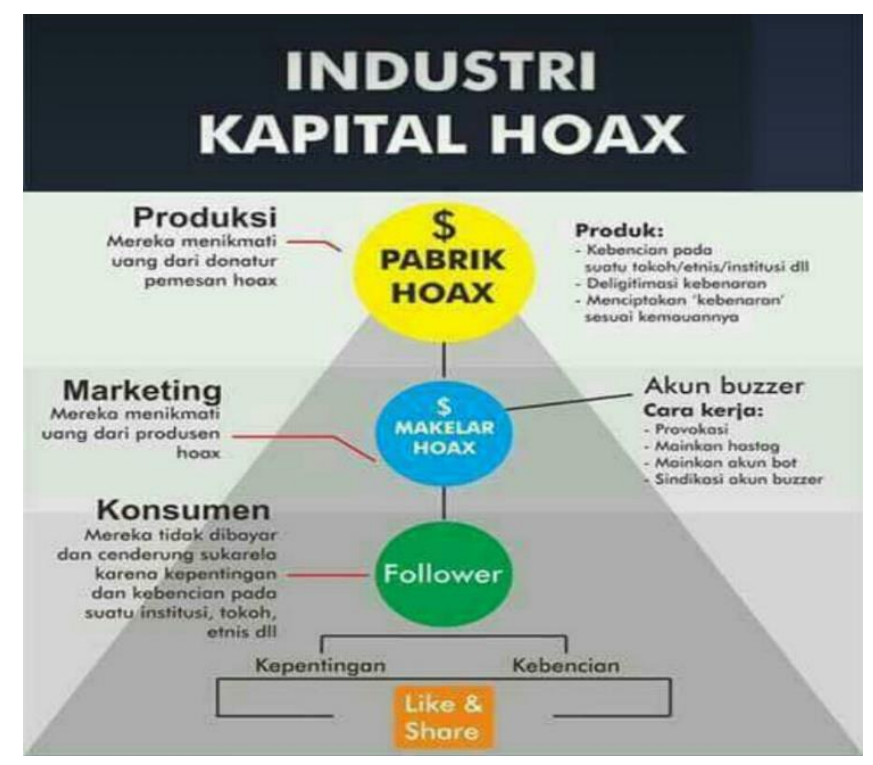

Gambar 1: Skema Ilustrasi Bisnis Proses Industri Kapital Hoax (Sumber: chirpstory.com, 2017) 
Banyak pihak mengasumsikan informasi hoax berupa teks ujaran kebencian pada ruang publik media sosial saat ini telah mengancam nilai-nilai kebebasan demokrasi di Indonesia. Fenomena ini bukan dikarenakan kesalahan pada teknologi yang digunakan, melainkan tingkat kesadaran pengguna teknologi informasi dan komunikasi (TIK) global itu sendiri. Terungkapnya kasus sindikat Saracen pada tahun 2017 misalnya. Hal ini menunjukkan bahwa informasi hoax berupa teks ujaran kebencian telah diproduksi menjadi industri kapital bisnis, seperti yang dikonsepkan dalam artikel ini.

Industri informasi teks ujaran kebencian seperti yang terlihat dalam Gambar 1 terstruktur rapi layaknya industri legal. Industri kapital hoax tersebut telah memproduksi dan memasarkan informasi melalui para agen, kemudian membentuk follower sebagai konsumen. Distribusi dan keberadaan hoax ujaran kebencian ini dipengaruhi oleh nilai ekonomi, yang secara financial menguntungkan bagi para aktor pelakunya. Pertama, aktor-aktor tersebut mengahsilkan nilai ekonomi karena bisnis yang berjalan. Kedua, mereka juga memperoleh nilai kekuasaan politik, karena sasaran dan tujuan dalam melemahkan pihak lawan tercapai. Meski memiliki struktur organisasi yang lengkap, seperti yang terjadi pada Saracen, tetap saja sistem operasionalnya bersifat ilegal. Sistem operasional tersebut umumnya dikonstruksi sehingga mirip bisnis perusahaan corporate. Berikut konsep operasional Saracen, yang terbongkar aparat Kepolisian belakangan ini.

"Dalam satu proposal yang kami temukan, kurang lebih setiap proposal nilainya puluhan juta," ujar Kasubdit di Direktorat Tindak Pindana Siber Bareskrim Polri, Kombes Irwan Anwar, seperti dikutip dari Detik.com. Tiga tersangka yang ditangkap yakni MFT, 43, yang berperan membidangi media dan informasi situs aracennews.com, SRN, 32, yang berperan sebagai koordinator grup wilayah, dan $J A S$, 32, yang berperan sebagai ketua. Tersangka JAS diketahui memiliki kemampuan memulihkan akun media sosial anggotanya yang kena blokir. "Dia juga memberi bantuan pembuatan berbagai akun, baik yang sifatnya real, semi-anonim, maupun anonim" (bbcindonesia, 2017).

Konsep bisnis teks ujaran kebencian pada media sosial ini telah berkembang secara global, seperti pada Pilpres Amerika Serikat (2017). Kemenangan Donald Trump atas Hillary Clinton dapat kita baca melalui teks ujaran kebencian pada media-media internasional, termasuk juga media sosial. Salah satu kampanye politik Trump yang menjadi viral di media sosial kala itu menyangkut penolakannya terhadap "imigran muslim" yang masuk ke Amerika (Nazila, 2013).

Fenomena yang mirip juga telah kita saksikan pada penyelenggaraan Pilpres Indonesia (2014) yang ramai dengan isu komunis (PKI) dan SARA. Terakhir ramai diperbincangkan yaitu Pilgub DKI Jakarta (April 2017) dengan isu reklamasi teluk Jakarta, hingga terbongkarnya kasus Saracen. Grup Saracen yang diduga sebagai produsen, telah menerima keuntungan dari para donatur tertentu sebagai imbalan jasanya dalam memproduksi teks ujaran kebencian yang ditujukan kepada tokoh/ pihak/ kelompok/ institusi tertentu. Produsen tersebut memiliki banyak agen/makelar yang tersebar di berbagai wilayah, yang berperan dalam melegitimasi kebenaran yang diciptakan untuk mendukung konstruksi teks 
ujaran kebencian yang telah diproduksi dan disebarkannya. Pola kerjanya tidak tampak di permukaan, bahkan sengaja dirahasiakan seperti halnya cara kerja intelijen, tetapi dengan target tertentu.

Aktor-aktor ekonomi politik ini bekerjasama dengan para agen dan buzzer yang memiliki banyak follower dan pasar yang besar di media sosial. Tugas para agen adalah melakukan provokasi berita, klarifikasi isu, serta memainkan hashtag melalui pembuatan akun palsu dan sindikasi akun para buzzer di berbagai media. Semakin tinggi konsumsi berita politik bernada negatif akan membentuk cara pikir identifikasi politik yang negatif pula. Di sisi lain, semakin tinggi rasa percaya terhadap media, maka semakin tinggi keterikatan atas berita yang disampaikan (Indrajaya, Lukitawati; 2019). Kondisi ini berpotensi besar menimbulkan kebimbangan pada calon pemilih terhadap kegiatan pilkada maupun pemilihan umum lainnya, sehingga hasil survei yang biasanya diadakan sebelum pemilihan berlangsung dapat berbanding terbalik dengan hasil pemilihan yang sebenarnya. Seluruh isu sensitif yang dapat dikaitkan saat suatu event politik berlangsung dikonstruksi dan diperdebatkan pada ruang publik media sosial, sehingga menjadi viral dan mampu menggiring opini publik.

Tekanan dari opini publik yang dikonstruksikan pada media sosial tersebut berpengaruh terhadap pengambilan keputusan ekonomi dan politik pihak lawan. Fenomena seperti inilah yang dapat memaknai perhelatan percaturan ekonomi politik sebagai amunisi dalam Pilkada serentak (2018), serta menjelang Pemilu dan Pilpres 2019. Potensi tersebut diasumsikan akan mengganggu kebebasan berekspresi secara demokratis dalam konteks penggunaan ruang publik di media sosial. Sementara kebebasan berekpresi di ruang publik di media sosial merupakan tuntutan masyarakat global dalam berdemokrasi. Pertanyaan besarnya adalah masih relevankah konsep penggunaan ruang publik yang di populerkan Habermas (1989) tersebut untuk di terapkan pada media sosial.

\section{Kebebasan Berekspresi}

Konsep masyarakat demokrasi memiliki beberapa ciri, antara lain pluralistik, keberagaman agama, ras, setting sosial dan budaya. Karenanya, penting untuk menempatkan kebebasan berpendapat dengan hak asasi lainnya seperti berpikir, beragama, termasuk pola bermedia. Anne Weber (2009) dalam risetnya mengusulkan upaya menyeimbangkan kedua kepentingan tersebut.

Di satu sisi, ia memprioritaskan hak untuk mensosialisasikan semua gagasan tentang kebebasan berpikir, kebebasan berpendapat dan keyakinan agama kepada masyarakat. Pada sisi lain, Ia juga mensosialisasikan hak untuk menghormati kebebasan berpikir, kebebasan berpendapat dan keyakinan beragama itu sendiri. Pada titik inilah Anne Weber (2009) menekankan adanya keseimbangan karena kebebasan berekspresi juga bisa menjadi ancaman bagi hak untuk menghormati privasi individu/ kelompok. Terdapat risiko konflik antara kebebasan berekspresi dan larangan berekspresi yang mengandung unsur ujaran kebencian pada media manapun. Untuk mengantisipasi permasalahan ini, menurut Anne Weber (2009), berbagai negara telah mengatur wacana tentang ujaran kebencian secara eksplisit. 
Di Indonesia, permasalahan ini dapat mengacu pada SE/6/X/2015/ tanggal 8 Oktober 2015, seperti yang telah dijelaskan pada bagian lain artikel ini. Persoalan pentingnya adalah apakah ruang publik yang di konsepkan Habermas (1989) masih dapat menampung permasalahan tersebut ketika ruang publik yang di maksud telah berkembang ke ranah media sosial, dengan segala karakteristik dan budayanya, mencakup ranah-ranah yang masih dapat dijelaskan, begitupun yang tidak, sehingga harus di jelaskan melalui konsep lain.

\section{Ruang Publik di Media Sosial}

Keberadaan ruang publik di media sosial saat ini tidak hanya mampu mengubah pola komunikasi antar masyarakat (netizen). Pada versi tertentu media sosial menjadi ruang publik yang bersifat demokrasi siber (cyber democracy). Kebebasan mendapatkan informasi, dan ruang dialogis membuat setiap individu mampu mengambil keputusan. Habermas, dalam Oliver (1995) menggambarkan konsep ideal demokrasi dalam ruang publik yaitu ruang bebas bagi setiap warga untuk mengkomunikasikan pendapatnya dan berdialog secara logis tanpa ada tekanan dari pihak manapun.

Seiring dengan perkembangan TIK, berjejaring internet, ruang publik kini merambah ke dalam bentuk media sosial. Karena sifatnya yang global, maka kebebasannya bisa tanpa batas. Dengan demikian, ruang tersebut juga dengan mudah dimasuki kekuatan intervensi lain, seperti ekonomi-politik, sosial, budaya, teknologi dan kekuatan global lainnya. Adanya potensi tekanan ekonomi politik tertentu membuat media sosial semakin menjauh dari posisinya sebagai penyedia ruang publik (public sphere) yang komunikatif dan demokratis.

Habermas (1989) menyebut tiga syarat munculnya ruang publik, yaitu: ketiadaan status, kepentingan bersama, dan inklusivitas. Kriteria pertama, ketiadaan status, ditandai dengan tidak adanya pembatasan individu yang ingin masuk dan berdiskusi dalam media sosial. Ketiadaan status ini juga terlihat dari tidak adanya pembagian masyarakat berdasarkan kelas sosial tertentu. Hal ini karena semua individu yang berada di media sosial tergabung menjadi penggunanya. Kriteria kedua, aspek kepentingan bersama, ditandai dengan banyaknya isu yang terdapat di media sosial umumnya adalah berbagai masalah yang menyangkut kepentingan individu maupun masyarakat di dunia nyata. Sedangkan kriteria ketiga, inklusivitas, juga terdapat dalam media sosial karena sifatnya yang sangat inklusif dan terbuka bagi setiap orang. Merujuk pada sifatnya yang global menyebabkan jumlah masyarakat pengguna media sosial menjadi beragam dan tidak terbatas, yang mana dapat melakukan hal apapun dalam realitas pada ruang publik media sosial.

Berpijak dari kebebasan yang di milikinya, ruang publik di media sosial bukan lagi hanya ditujukan untuk kegiatan yang bersifat legal, tetapi juga menjadi ajang praktik perhelatan kepentingan ekonomi politik yang ilegal oleh para aktor tertentu. Seiring dengan perjalanan waktu dan perkembangan teknologi informasi dan komunikasi (TIK) yang semakin pesat, konsep ruang publik Habermas (1989) sudah tidak relevan untuk menjelaskan ruang publik pada media sosial. Seperti dijelaskan sebelumnya, pengguna media sosial dapat bertindak sebagai prosumer, 
yakni produsen dan konsumen konten secara bersamaan, bahkan mereka dapat mereproduksi dan membagikan konten-konten tersebut kepada siapapun.

Mengacu pada konteks tersebut, jika hanya dijelaskan menggunakan pandangan Habermas (1989), menjadi kurang relevan secara konseptual, juga mengalami hambatan yang signifikan ketika dihadapkan pada kondisi bahwa pengguna ruang publik di media sosial mampu bertindak sebagai prosumer, dimana karakteristik ini dianggap sebagai pembeda dengan media lain. Maka untuk menjelaskan penggunaan ruang publik di media sosial, diperlukan dukungan konsep lainnya yang sejalan dengan karakteristik media sosial.

\section{Simpulan}

Perkembangan media baru berbanding lurus dengan peningkatan teror dan kejahatan siber. Kemampuan masyarakat dalam menyaring informasi yang diterima belum dapat mengimbangi cepatnya arus informasi yang beredar. Sebagian besar masyarakat masih menelan mentah-mentah seluruh konten informasi yang didapat tanpa melakukan verifikasi, terutama pada media sosial.

Berangkat dari karakteristiknya yang bersifat bebas, global, berformat digital, serta tanpa sekat ruang dan waktu, penggunaan media sosial jika hanya dilihat dari konsep Habermas (1989) tentang penggunaan ruang publik, sudah tidak dapat berfungsi secara optimal. Pada satu sisi ruang publik di media sosial masih berfungsi sebagai arena komunikasi serta tempat bertukar pemikiran dan ilmu pengetahuan secara dialogis. Namun di sisi lain, dalam konteks tertentu, karakteristik dan kebebasan yang dimilikinya dapat berimplikasi negatif jika penggunanya tidak mengindahkan tata nilai yang ada. Tanpa adanya kode etika profesi yang melekat, pengguna sekaligus konsumen media sosial dapat melalukan reproduksi berbagai konten sesuai dengan keinginannya.

Pemaknaan: melihat evolusi karakter pada ruang publik, penggunaan media sosial berimplikasi pada aspek lain diluar konsep awal Habermas (1989). Ruang publik tersebut telah berkembang dan dimanfaatkan oleh aktor-aktor tertentu dalam menebar teks ujaran kebencian kepada individu/kelompok/organisasi yang berbeda pandangan demi tercapainya tujuan dan kepentingan suatu pihak. Berdasarkan fenomena tersebut, dapat dimaknai bahwa ruang publik pada media sosial secara utuh tidak lagi hanya berfungsi sebagai sarana komunikasi, tempat bertukarnya nilai-nilai secara dialogis, independen dan demokratis. Adanya tekanan dari berbagai aspek telah berimplikasi pada hal-hal lain di luar konsep sebelumnya, dan untuk menjelaskannya perlu didukung konsep baru yang selaras dengan perkembangan karakteristik media social saat ini.

Pengaruh: kebebasan ruang publik di media sosial sebagian telah difungsikan untuk tujuan lain di luar konsep Habermas (1989). Penyebaran teks ujaran kebencian dilakukan sebagai upaya penyerangan/ provokasi terhadap kelompok tertentu yang memiliki pandangan dan ideologi yang berbeda, sehingga realitas media tersebut menjadi realitas sosial. Dampak yang dianggap paling menonjol atas pergeseran fungsi ruang publik pada media sosial diantaranya perubahan kebutuhan nilai (ekonomi dan politik) dari para aktor tertentu untuk 
meraih keuntungan finansial dan tujuan politik tertentu. Persebaran teks ujaran kebencian yang tersebar semakin masif telah memperkuat argumen dalam artikel ini. Terkuaknya jaringan Saracen, yang memiliki kekuatan ekonomi dan politik merupakan salah satu fenomena nyata yang menunjukan bahwa moda ekonomi kapitalis dan kekuatan politik pragmatis setidaknya berelasi terhadap kebebasan demokrasi, serta independensi penggunaan ruang publik di media sosial.

Rekomendasi: pemerintah telah mengeluarkan surat edaran dan beberapa regulasi sebagai upaya mengendalikan persebaran teks ujaran kebencian di jaringan maya. Meskipun aturan dan sangsi telah tertera dengan jelas, jumlah peredaran hate speech masih terus meningkat. Karenanya perlu dilakukan pendekatan lain dari sisi pengguna, salah satunya dengan mengedukasi masyarakat secara aktif tentang literasi digital. Masyarakat, khususnya pengguna media sosial perlu didorong untuk menjadi kritis dalam menilai suatu informasi, antara lain dengan membandingkan beberapa sumber berita dari sudut pandang berbagai pihak agar informasi yang didapat berimbang; memberi feedback pada kolom komentar untuk menjalin komunikasi dua arah antara media dan audiens; memverifikasi kebenaran suatu berita sebelum membagikan informasi tersebut; serta melaporkan konten informasi yang bersifat negatif kepada pihak yang ditunjuk pemerintah.

Kelemahan artikel ini yaitu tidak didukung dengan data hasil kajian tentang identifikasi potensi penyebaran ujaran kebencian baik di media mainstream maupun media baru, sehingga perlu dilakukan studi lanjutan untuk memetakan pola persebaran pesan ujaran kebencian dan bagaimana mengontrol persebarannya di berbagai media.

\section{Daftar Pustaka}

BBC News Indonesia. (2017). Kasus Saracen: Pesan kebencian dan hoax di media sosial 'memang terorganisir'. 24 Agustus 2017. https://www.bbc.com/indonesia/trensosial-41022914.

Chazawi, Adami \& Ardi Ferdian. (2011). Tindak Pidana Informasi \& Transaksi Elektronik Penyerangan Terhadap Kepentingan Hukum Pemanfaatan Teknologi Informasi dan Transaksi Elektronik. Malang: Banyumedia Publishing.

Chirpstory. (2017). Membongkar Industri Kapital Hoax. Oleh @santriGD. https://chirpstory.com/li/343766.

Ghanea, Nazila. (2013). Intersectionality and the Spectrums of Racist Hate Speech: Proposals to the UN Committee on the Elimination of Racial Discrimination. Human Right Quarterly, 35:935-954. https://www. scribd.com/document/274008777/Intersectionality-and-the-Spectrum-ofRacist-Hate-Speech-Proposals-to-the-UN-Committee-on-the-Eliminationof-Racial-Discrimination.

Habermas, Jurgen. (1989). The Structural Transformation of the Public Sphere: An Inquiry into a Category of Bourgeois Society. Cambridge: Polity.

Herring, Susan. (2008). Questioning the generational divide: technological exoticism and adult constructions of online youth identity, in David 
Buckingham (ed.) Youth, Identity and Digital Media. Cambridge, MA \& London: The MIT Press 2008, pp. 71-94.

Indrajaya, S. E., dan Lukitawati, L. (2019). Tingkat Kepercayaan Generasi Z terhadap Berita Infografis dan Berita Ringkas di Media Sosial. Jurnal Komunikasi, $11(2)$, pp. 169-182. https://journal.untar.ac.id/index.php/komunikasi/article/view/5045

Jenkins, Ford., \& Green. (2009). Spreadable Media: Creating Value and Meaning in a networked Culture. New York: New York University Press.

Johnson, R. Burke, Onwuegbuzie, A.J. (2004). Mixed Methods Research: A Research Paradigm Whose Time Has Come. Educational Researcher, 33(7), pp. 14-26.

Kitab Undang-Undang Hukum Pidana (KUHP).

McDevitt, J., Levin, J., \& Bennett, S. (2002). Hate Crime Offenders: An Expanded Typology. Journal of Social Issues, 58(2), pp. 303-317.

McKee, Alan. (2005). The Public Sphere: An Introduction. Cambridge: Cambridge University Press.

Napoli, P. M. (2016). The Audience as Product, Consumer, and Producer in the Contemporary Media Marketplace. Managing Media Firms and Industries, Media Business and Innovation, pp. 261-275.

Oliver, Boyd-Barrett., \& Newbold, Chris. (1995). Approaches to Media: A Reader. London: Arnold.

Sibert, Freds, et all. (1973). Four Theories of The Press. Chicago: University Illinois Press Urbana.

Taylor, Robert S. (2012). Hate Speech, The Priority of Liberty, and the Temptations of Nonideal Theory: Ethic Theory Moral Prac. 15:353-368. http://eresources.go.id/10.1007/s10677-011-9287-6.

Tempo. (2018). Hate Speech di Media Sosial, Intip 3 Jurus Menghindarinya. Anastasia Pramudita D. Tempo, 30 Maret 2018.

Undang Undang nomor 11 tahun 2008 tentang Informasi dan Transaksi Elektronik.

Undang Undang nomor 40 tahun 2008 tentang Penghapusan Diskriminasi Ras dan Etnis.

Vainikka, E., Herkman, J. (2013). Generation of content-producers? The reading and media production practices of young adults. Participations, Journal of Audience \& Receptions Studies, 10(2), pp. 118-138.

Weber, Anne. (2009). Manual on Hate Speech. Council of Europe Publishing F.67075. Strasbourg Cedex, http://book.coe.int/9/10/17. 